Bachtaruddin., dkk, Kualitas Bahan.... 1435

\title{
KUALITAS BAHAN KERING DAN BAHAN ORGANIK PAKAN KOMPLIT FERMENTASI BERBASIS DAUN GAMAL SECARA IN VITRO
}

\author{
Bachtaruddin Badewi dan Bambang Hadisutanto \\ Jurusan Peternakan, Politeknik Pertanian Negeri Kupang \\ J. Prof. Dr. Herman Yohanes, Lasiana Kupang, P.O.Box. 1152, Kupang 85011 \\ Korespondensi:bhadisutanto@gmail.com
}

\begin{abstract}
This study used a completely randomized design with complete feed fermentation time of 0, 3, 6, 9 weeks. The variables observed were the digestibility quality of dry matter and organic matter in vitro. The results showed that the dry matter digestibility of the complete fermented feed at week $O$ (48.508\%) and 6 weeks (48.17\%) was not significantly different. Meanwhile, the complete dry matter digestibility at the fermentation time of 3 weeks (51.474\%) and 9 weeks (44.558\%) showed a significant difference. The conclusions of this study are: 1. The dry matter digestibility of fermentation for $O$ weeks (48.508\%) and 6 weeks (48.17\%) was not significantly different. 2. Digestibility of organic matter with fermentation time of 0 weeks and 3 weeks did not show any difference but was significantly different from complete feed with 6 weeks and 9 weeks of storage.
\end{abstract}

Keywords: Long Fermentation, In Vitro, Digestibility

\section{PENDAHULUAN}

Produktivitas ternak ruminansia di Indonesia masih tergolong rendah. Salah satu faktor penyebabnya adalah tingkat kecernaan. Pemberian pakan berkualitas rendah akan menurunkan nilai kecernaan dalam sistem rumen. Tingkat kecernaan pada ruminansia dipengaruhi oleh populasi mikroba di dalam rumen. Bakteri merupakan jenis mikroba rumen yang mampu menghasilkan enzim selulase dan hemiselulase untuk menghidrolisis dinding sel tanaman pakan.

Ternak ruminansia khususnya kambing memerlukan pakan hijauan sebagai sumber serat dan sumber energi. Serat dalam pakan utamanya berfungsi sebagai sumber energi dan menjaga fungsi normal rumen serta aktivitas mikroba rumen. Keberadaan pakan sumber serat sejak dulu sering menjadi permasalahan baik dilihat dari segi kualitas maupun kesinambungannya. Berdasarkan kondisi tersebut, memunculkan peluang untuk memanfaatkan pakan sumber serat yang ketersediaannya dalam jumlah besar, murah dan berkesinambungan, di antaranya daun gamal, klobot jagung, tepung putak, dedak padi dan tepung ikan. 
Gamal (Gliricidia sepium) merupakan salah satu hijauan yang disukai oleh ternak ruminansia. Tanaman ini tumbuh subur di daerah lahan kering seperti Kupang dan hampir tersedia sepanjang tahun walaupun volume daunnya tidak sebanyak waktu musim penghujan. Klobot atau kulit jagung merupakan limbah yang tidak dimanfaatkan. Klobot jagung dari jenis jagung fulut ini banyak dijumpai di sentra penjualan jagung siap saji di desa Oesao kecamatan Kupang Timur. Tepung putak yang diproduksi oleh industri rumah tangga petani di desa Oelamasi merupakan sumber pakan yang tidak bersaing dengan kebutuhan manusia. Tepung ikan yang berasal dari remukan/ikan yang hancur hasil pembuatan ikan asin di pasar ikan Oesapa Kupang yang tidak memiliki nilai ekonomi lagi.

Bahan pakan yang digunakan dalam pembuatan pakan komplit fermentasi merupakan bahan pakan lokal yang banyak terdapat di wilayah Kupang Nusa Tenggara Timur. Hingga saat ini belum ada identifikasi bahan pakan lokal dilakukan secara survei pada wilayah Kupang dan sekitarnya. Namun identifikasi dilakukan terhadap bahan-bahan pakan lokal yang disukai ternak (palatabel) dan sudah digunakan sebagi pakan ternak oleh penduduk atau peternak setempat. Di samping itu harus memenuhi syarat mudah diperoleh, tidak bersaing dengan manusia, kontinyuitas atau ketersediaannya selama setahun dan harga murah. Bahan pakan lokal tersebut dapat berupa sisa limbah pertanian, perkebunan, limbah pasar, industri dan rumah tangga (Nuraini, dkk., 2016).

Bahan-bahan tersebut merupakan limbah pertanian yang cukup besar jumlahnya dan belum sepenuhnya dimanfaatkan sebagai pakan alternatif sumber serat bagi ternak kambing. Bahan yang terdiri dari daun gamal, klobot jagung, tepung putak, dedak padi dan tepung ikan diformulasi menjadi satu formulasi pakan komplit yang selanjutnya dilakukan fermentasi kering dengan lama fermentasi bervariasi yaitu 0 minggu, 3 minggu, 6 minggu dan 9 minggu.

Kecernaan pakan sangat penting diketahui untuk menentukan suatu bahan pakan. Pengukuran kecernaan dapat dilakukan salah satunya dengan teknik in vitro. Teknik in vitro sering disebut dengan teknik rumen buatan yaitu suatu percobaan fermentasi bahan pakan secara anaerob dalam tabung fermentor dan menggunakan larutan penyangga yang merupakan saliva buatan. Evaluasi kecernaan pakan yang dilakukan dapat diketahui kecernaan bahan kering, kecernaan bahan organik, produksi VFA dan amonia $\left(\mathrm{NH}_{3}\right)$. 
Kandungan serat kasar yang tidak terlalu tinggi menyebabkan kecernaan menjadi tinggi dan dapat berakibat pada tingginya volatile fatty acids (VFA). Kecernaan pakan sangat penting diketahui untuk menentukan kualitas pakan komplit fermentasi. Evaluasi kecernaan pakan komplit fermentasi yang dilakukan dalam penelitian ini meliputi kecernaan bahan kering dan kecernaan bahan organik.

Tujuan dari penelitian ini adalah membandingkan kualitas kecernaan bahan kering dan bahan organik pakan komplit berbasis gamal yang difermentasi selama 0 minggu, 3 minggu, 6 minggu dan 9 minggu secara in vitro.

\section{METODE PENELITIAN}

\section{Lokasi dan Waktu Penelitian}

Penelitian ini dilakukan di Laboratorium Nutrisi dan Pakan Ternak Politeknik Pertanian Negeri Kupang selama 3 bulan yaitu bulan Juni - Agustus 2020 .

\section{Bahan Penelitian}

Bahan yang akan digunakan dalam penelitian ini di antaranya (1) Daun gamal 60\%, (2) Klobot jagung 22\%, (3) Dedak padi 8\%, (4) Tepung putak 3\%, (5) Tepung ikan 7\%, (6) Plastik PC/Poly Carbonat volume 500 gram dengan ketebalan 0,8 mm, (7) Stiker nama untuk sampel pakan fermentasi, (8) karung pakan, (9) cairan rumen kambing dewasa.
a. Larutan penyangga (A)
g/liter
$\mathrm{KH} 2 \mathrm{PO} 4$
$10.0 \quad 5$
$\mathrm{MgSO} 47 \mathrm{H} 20$
$0,5 \quad 0,25$
$\mathrm{NaCI}$
$0,5 \quad 0,25$
$\mathrm{CaCI} 2$. 2H2O
$0,1 \quad 0,05$
Urea
$0,5 \quad 0,25$
b. Larutan penyangga (B)
$\mathrm{Na} 2 \mathrm{CO} 3$
Na2S. 9H2O

$\begin{array}{rr}15,0 & 7.5 \\ 1,0 & 0,5\end{array}$
c. Larutan Netral Deterjen

\section{Alat Penelitian}

Alat yang akan digunakan terdiri dari (1) Parang, (2) Timbangan digital merk Krisbow kapasitas 5 kg, (3) Thermometer ruangan, (4) Hygrometer, (5) 
perangkat kecernaan in vitro yang meliputi Inkubator DAISY", Perangkat filterkertas saring F57, Heat sealer-1915/1920, Termos, ANKOM200/220 Fiber Anlyzer

\section{Prosedur Penelitian}

\section{a. Persiapan Penelitian.}

Persiapan penelitian meliputi:

a. Menyiapkan putak untuk diproses menjadi tepung putak.

b. Menyiapkan tepung ikan yang bersumber dari limbah ikan di pasar ikan di Oeba dan Oesapa untuk diproses menjadi tepung ikan.

c. Menyiapkan kantung vakum/kedap udara yaitu kantung PC (Poly Carbonat) dengan ketebalan 0,8 $\mathrm{mm}$ dengan volume $5 \mathrm{~kg}$.

d. Meyiapkan daun gamal, klobot jagung, dedak padi, tepung putak dan tepung ikan.

e. Melakukan pencacahan klobot jagung.

f. Menyiapkan ternak kambing dewasa sebanyak satu ekor.

\section{b. Pelaksanaan Penelitian}

a. Melakukan penyesuaian cairan rumen kambing dengan jenis bahan pakan yang digunakan dalam uji kecernaan secara in vitro.

b. Kambing diberikan bahan pakan berupa campuran daun gamal, klobot jagung, dedak padi, tepung putak dan tepung ikan dalam bentuk pakan komplit selama 4 hari.

c. Melakukan penyembelihan ternak kambing untuk diambil cairan rumennya.

d. Menyiapkan sampel pakan komplit fermentasi untuk kecernaan in vitro.

e. Melakukan pencampuran daun gamal, klobot jagung, dedak padi, tepung putak, tepung ikan hingga merata kemudian dimasukkan ke dalam kantong plastik Poly Carbonat, dilakukan pengepresan hingga semua udara keluar, kemudian plastik diikat hingga diperoleh suasana kedap udara (anaerob) di dalam kantong palstik.

f. Setelah semua kantong plastik perlakuan diikat, dilakukan penyimpanan sesuai lama penyimpanan yaitu 0 minggu, 3 minggu, 6 minggu dan 9 minggu.

g. Setiap sampel perlakuan penelitian (200 gram) dimasukkan ke dalam kantong kertas kemudian dilakukan pengeringan di dalam oven pada suhu 60 derajat Celcius selama dua hari. 
h. Setiap sampel penelitian digiling hingga berbentuk tepung kemudian dimasukkan ke dalam plastik klip.

A. Persiapan Kertas Saring dan Sampel, yaitu:

a. Kertas saring F57 dibilas dengan aseton, kemudian dikeringkan selama 3 sampai 5 menit (kering udara). Pembilasan dengan aseton untuk membuka pori kertas saring sehingga memudahkan gelombang pencernaan mikroba.

b. Masing2 kertas diberikan kertas saring F57 diberi tanda label dan ditimbang untuk mengetahui beratnya (WI).

c. Tekan tombol zero/tare pada timbangan ,kemudian timbang sampel sebanyak 0,25 g langsung ke dalam kertas saring dan catat beratnya sebagai ( W2 ).

d. Segel tutup kertas saring menggunakan heat sealer 1915/1920.

e. Pengamatan dilakukan selama 48 jam.

B. Preparasi Larutan Penyangga (gabungan A $+B$, untuk setiap tabung pencernaan )

a. Menghangatkan larutan penyangga A dan B dalam inkubartor Daisy" pada suhu $39^{\circ} \mathrm{C}$. Dalam wadah terpisah, masukan $1330 \mathrm{ml}$ larutan A yang diukur secara tepat / teliti. Tambahkan $266 \mathrm{ml}$ larutan B ke dalam $1330 \mathrm{ml}$ larutan A ( RASIO 1:5 ).Jumlah larutan A harus tepat ; untuk larutan B harus sesuai sampai mendapatkan Ph yang diperlukan. Tambahkan 1600 ml gabungan campuran A/B ke setiap stoples pencernaan .

b. Menempatkan stoples pencernaan dengan sampel dan larutan buffer ke incubator Daisy" dan nyalakan sakelar panas dan agitasi. Biarkan penyesuaian suhu stoples pencernaan setidaknya 20-30 menit.

C. Persiapan inokulum dan inkubasi

Pertahankan semua peralatan gelas dan termos pada suhu $39^{\circ} \mathrm{C}$.

a. Memanaskan dua botol termos $2 \mathrm{~L}$ dengan mengisi air hangat kosong $39{ }^{\circ} \mathrm{C}$ Air hangat dibuang sesaat sebelum mengisi cairan rumen .ikuti prosedur pengambilan cairan rumen yang tepat, keluarkan kira2 2000 ml cairan rumen dan masukan ke dalam termos .Sertakan kira2 dua genggam isi rumen ke dalam satu termos.

b. Memanaskan dulu blender dengan mengisi air $39^{\circ} \mathrm{C}$.Kosongkan air hangat dari blender lalu masukan cairan rumen dari termos ke dalam blender. 
Bersihkan wadah blender dengan gas $\mathrm{CO} 2$ dan aduk pada kecepatan tinggi selama 30 detik. Pengadukan dengan blender berfungsi untuk melepaskan mikroba yang menempel pada material bahan pakan sehingga mendapatkan populasi mikroba representatif untuk fermentasi in vitro. Saring digesta dari blender dengan 4 lapis kain katun tipis ke dalam labu 5 liter 9 pra -pemanasan $39^{\circ} \mathrm{C}$ ).Saring juga cairan rumen yang tersisa ditermos lainnya menggunakan empat lapis kain katun tipis ke dalam labu lima liter yang sama.

c. Mengeluarkan satu stoples pencernaan dari incubator Daisy II dan tambahkan inoculum $400 \mathrm{ml}$ ke larutan penyangga dan sampelnya .Bersihkan stoples pencernaan dengan gas $\mathrm{CO} 2$ selama 30 detik dantutup rapat.

d. Inkubasi selama 48 jam

e. Setelah selesai proses inkubasi, keluarkan stoples dan tiriskan cairan . Bilas semua kantong sampel dengan air keran dingin hingga bersih.

f. Mengeringkan fiber bag (kantong sampel) dalam oven. Menimbang dan mencatat berat in vitro sebagai W3

Menghitung :

$\% \operatorname{IVTD}=\frac{(W 3-(W 1 * C 1))}{W 2} * 100$

$\% \operatorname{IVTDDM}(\mathrm{DM}$ basis $)=\frac{100-\left(W_{2}-\left(W_{1} * C 1\right)\right)}{W 2 * D M} * 100$

Di mana :

$\mathrm{W}_{1}=$ berat kantong kosong

$\mathrm{W}_{2}=$ berat sampel

$\mathrm{W}_{3}=$ berat kantong + sampel akhir setelah perlakuan in vitro

$\mathrm{C}_{1}=$ Kantong kosong koreksi ( akhir oven kering berat/berat kantong kosong)

\section{Variabel yang Diamati}

Kecernaan merupakan suatu rangkaian proses yang terjadi di dalam alat pencernaan sampai terjadinya penyerapan. Variabel yang diamati adalah (1) Kecernaan Bahan Kering dan (2) Kecernaan Bahan Organik.

\section{Rancangan Percobaan dan Analisis Data}

Rancangan yang digunakan dalam penelitian ini adalah Rancangan Acak Lengkap (RAL) dengan perlakuan pakan komplit fermentasi dengan lama 
penyimpanan 0 minggu, 3 minggu, 6 minggu dan 9 minggu yang diulang sebanyak 5 kali.

Analisis data meliputi analisis varian dan uji lanjut DMRT untuk mengetahui perbedaan antar perlakuan.

\section{HASIL DAN PEMBAHASAN}

\section{Kecernaan Bahan Kering}

Kecernaan bahan kering suatu bahan adalah kecernaan bahan organik dan anorganik bahan pakan tersebut. Kecernaan bahan kering yang tinggi menunjukkan tingginya nutrien yang dicerna. Semakin tinggi kecernaan suatu bahan pakan, berarti semakin tinggi kualitas bahan pakan tersebut. Kecernaan bahan kering in vitro menunjukkan proporsi bahan kering ransum yang dapat dicerna oleh mikroba rumen. Kecernaan bahan kering mampu menunjukkan kualitas pakan dan besarnya kemampuan ternak dalam memanfaatkan suatu jenis pakan (Rahman, dkk., 2013).'

Rataan hasil penelitian kecernaan bahan kering pakan komplit ternak kambing dengan lama fermentasi yang berbeda secara in vitro disajikan pada Tabel 1.

Tabel 1. Rataan Kecernaan Bahan Kering dan Bahan Organik Pakan Komplit dengan Lama Fermentasi Berbeda Secara In Vitro
No.
Kecernaan (\%)
Lama Fermentasi (minggu)
$\begin{array}{llll}0 & 3 & 6 & 9\end{array}$

\begin{tabular}{|c|c|c|c|c|}
\hline Bahan Kering & $48,508 \pm 0,55$ & $51,508 \pm 1,18$ & $48,17 \pm 0,73$ & $44,558 \pm 0,73$ \\
\hline Bahan Organik & $49,20 \pm 1,09$ & $50,98 \pm 1,41$ & $46,99 \pm 0,84$ & $43,936 \pm 1,90$ \\
\hline
\end{tabular}

Sumber: Hasil Analisis Laboratorium Nutrisi dan Pakan Ternak Politani Negeri Kupang 2020.

Hasil analisis statistik penelitian ini menunjukkan bahwa kecernaan bahan kering pakan komplit fermentasi 0 minggu (48,508\%) dan 6 minggu $(48,17 \%)$ tidak berbeda nyata $(\mathrm{P}>0.05)$. Sedangkan kecernaan bahan kering pakan komplit lama fermentasi 3 minggu (51,474\%) dan 9 minggu (44,558 \%) menunjukkan perbedaan nyata $(\mathrm{P}<0.05)$. 
Tingginya tingkat kecernaan bahan kering pakan komplit dengan lama fermentasi 3 minggu menunjukkan terjadinya proses perenggangan terhadap ikatan lignosellulosa dan lignohemisellulosa pada pakan komplit lama fermentasi 3 minggu sehingga akan meningkatkan kecernaan bahan kering. Hal ini sesuai dengan pendapat Andayani (2010) yang menyatakan bahwa proses perenggangan terhadap ikatan lignosellulosa dan lignohemisellulosa pada pakan dapat meningkatkan kecernaan bahan kering. Hal ini membuktikan bahwa lama fermentasi 3 minggu terhadap pakan komplit penelitian ini dapat meningkatkan kecernaan bahan kering sehingga memberikan harapan baik untuk meningkatnya nilai nutrient pakan.

Kecernaan in vitro bahan kering menunjukkan proporsi bahan kering yang dapat dicerna oleh mikroba di dalam rumen. Hasil penelitian Hambakodu dan Ina, (2019) pada bahan pakan ampas tahu menunjukkan bahwa kecernaan bahan kering yang tinggi sangat dipengaruhi oleh kandungan lignin yang rendah dan tingginya protein kasar. Kandungan lignin yang rendah memberikan peluang bagi mikroba rumen untuk mencerna pakan secara optimal di dalam rumen. Tingginya kecernaan bahan kering maupun bahan organik sangat dipengaruhi oleh proporsi protein sebagai sumber $\mathrm{N}$ bagi mikroba rumen, sedangkan karbohidrat sebagai kerangka karbon untuk mendukung sintesis protein rumen serta sumber energi bagi ternak induk semang (Syaputra, dkk., 2013).

Sintesis protein mikroba tinggi apabila kecernaan bahan kering tinggi terutama nutrien protein kasar dan karbohidrat mudah larut. Peningkatan sintesis protein mikroba disebabkan tersedianya nutrien yang cukup seperti karbohidrat fermentable (Syapura, dkk., 2013). Rendahnya tingkat kecernaan bahan kering pakan komplit dengan lama fermentasi 6 minggu dan 9 minggu disebabkan kandungan lignin pakan komplit sehingga menyebabkan rendahnya nilai kecernaan di dalam rumen. Hal ini disebabkan karbohidrat (dedak padi dan tepung putak) yang merupakan kerangka karbon sudah menipis atau habis sehingga tidak mendukung sintesis protein rumen. Sedangkan pakan komplit dengan lama fermentasi 0 minggu, persediaan karbohidrat (dedak padi dan tepung putak) masih cukup tersedia namun pakan komplit tersebut belum mengalami fermentasi.

\section{Kecernaan Bahan Organik}

Kecernaan in vitro bahan organik menunjukkan proporsi bahan organik yang dicerna oleh enzim pencernaan yang dihasilkan oleh mikroba di dalam 
rumen. Analisis ragam menunjukkan kecernaan bahan organik berbeda nyata $(\mathrm{P}<0.05)$. Hasil uji Duncan (DMRT) menunjukkan bahwa kecernaan bahan organik pakan komplit dengan lama fermentasi 0 minggu dan 3 minggu tidak menunjukkan perbedaan tetapi berbeda nyata dengan pakan komplit dengan lama penyimpanan 6 minggu dan 9 minggu (Tabel. 1).

Nilai kecernaan bahan organik lebih tinggi dibandingkan nilai kecernaan bahan kering disebabkan dalam kecernaan bahan kering masih mengandung abu dan pada kecernaan bahan organik sudah tidak mengandung abu. Abu dalam bahan kering berdampak terhadap lambatnya daya cerna bahan kering pakan, sehingga bahan organik tanpa kandungan abu lebih mudah dicerna mikroba rumen (Putra, dkk., 2019).

Penurunan kecernaan bahan organik pada pakan komplit dengan lama fermentasi 6 minggu dan 9 minggu diduga karena kemampuan mikroba rumen dalam menerima nutrisi telah melebihi batas maksimal sehingga mikroba rumen tidak mampu memanfaatkan, sehingga berdampak pada penrunan aktivitas mikroba rumen (Dewi, dkk., 2019).

\section{KESIMPULAN}

Hasil yang dapat disimpulkan dari penelitian ini adalah:

a. Kecernaan bahan kering pakan komplit fermentasi 0 minggu (48,508\%) dan 6 minggu $(48,17 \%)$ tidak berbeda nyata $(\mathrm{P}>0.05)$. Sedangkan kecernaan bahan kering pakan komplit lama fermentasi 3 minggu (51,474\%) dan 9 minggu $(44,558 \%)$ menunjukkan perbedaan nyata $(\mathrm{P}<0.05)$.

b. b.Kecernaan bahan organik pakan komplit dengan lama fermentasi 0 minggu dan 3 minggu tidak menunjukkan perbedaan tetapi berbeda nyata dengan pakan komplit dengan lama penyimpanan 6 minggu dan 9 minggu. 


\section{DAFTAR PUSTAKA}

Andayani. (2010). Evaluasi Kecernaan In Vitro Bahan Kering, Bahan Organik dan Protein Kasar Penggunaan Kulit Buah Jagung Amoniasi dalam Ransum Ternak Sapi. Jurnal Ilmiah Ilmu-Ilmu Peternakan Februari, 2010, Vol. XIII, No. 5.

Hambakodu, M. danYessy Tamu Ina. 2019. Evaluasi Kecernaan In Vitro Bahan Pakan Hasil Samping Agro Industri. Jurnal Agrivet, Vol 19, No. 1, April 2019.

Putra, G.Y., Herni Sudarwati., Mashudi (2019). Pengaruh Penambahan Fermentasi Kulit Pisang Kepok (Musa paradisiaca L) Pada Pakan Lengkap terhadap Kandungan Nutrisi dan Kecernaan Secara In Vitro. Jurnal Nutrisi Ternak Tropis. Vol 2 No 1 pp 42-52.

Rahman, Andi Murlina Tasse dan Dian Agustina. 2013. Pengaruh Penambahan Tepung Daun Sisik Naga (Drymoglosum pilloselloides) terhadap Kecernaan In Vitro Konsentrat berbahan In Vitro Konsentrat Berbahan Pakan Fermentasi. Jurnal Agriplus Volume 23, Nomor 03 September 2013.

Syapura, Bata, M., Pratama, W.S., 2013. Peningkatan Kualitas Jerami Padi dan Pengaruhnya terhadap Kecernaan Nutrien dan Produk Fermentasi Rumen Kerbau dengan Feses Sebagai Sumber Inokulum. Jurnal Agrivet 13 (2): 5967. 